\title{
PENYUSUTAN DOKUMEN PERUSAHAAN \\ DI PT KERETA API INDONESIA (PERSERO)
}

\author{
Nabila Azzahra, A. Md. \\ Kementerian Desa, Pembangunan Daerah Tertinggal, dan Transmigrasi RI \\ (nabila.azzahra.2013@gmail.com)
}

\begin{abstract}
INTISARI
Penelitian berjudul Penyusutan Dokumen Perusahaan di PT. Kereta Api Indonesia (Persero) bertujuan untuk mengkaji tentang bagaimana kegiatan penyusutan dokumen perusahaan di PT. Kereta Api Indonesia (Persero). Kajian ini menjelaskan mengenai penyusutan dokumen perusahaan yang dilakukan dengan cara penilaian dengan nilai guna dan berdasarkan jadwal retensi arsip. Penyusutan dokumen perusahaan di PT. Kereta Api Indonesia (Persero) belum berjalan dengan baik. Penyusutan dilakukan melalui pemindahan, pemusnahan, dan penyerahan dokumen perusahaan. Proses penyusutan dilakukan setelah proses verifikasi antara daftar arsip dengan fisik arsip selesai dilaksanakan. Pemindahan dokumen perusahaan dilaksanakan secara berkala dari central file ke records center, dengan diterbitkan berita acara yang dilampiri daftar arsip. Pemusnahan dokumen perusahaan belum dilaksanakan karena SOP pemusnahan dan jadwal retensi arsip masih dalam proses pembahasan dan legalisasi. Penyerahan dilaksanakan untuk menyerahkan arsip yang memiliki nilai guna sekunder ke Arsip Nasional Republik Indonesia yang disertai berita acara dan daftar arsip.
\end{abstract}

Kata Kunci: dokumen perusahaan, penilaian, penyusutan.

\section{ABSTRACT}

This research entitled Disposal Corporate Documents in PT. Kereta Api Indonesia (Persero). The purpose of this research was to inform how the activities of disposal in PT. Kereta Api Indonesia (Persero). This research describes the company documents that are conducted by appraising with the value of use and based on the archives retention schedule. Disposal the corporate document PT. Kereta Api Indonesia (Persero) has not been fully implemented. Disposal archives rope transfer, disposal, and acquisition archives. The disposal process are done after the verification on the list of archives with the physical archive finished. The transfer of records conducted periodically from central file to the records center, accompanied by official report and list of archives. For disposal corporate document has not carried out because SOP of disposal and the archives retention schedule in the discussion process. Archives acquisition conducted archives that have a secondary value to the national archives of Republic Indonesia, accompanied by an official report and a list of archives.

Keywords: appraisal, corporate documents, disposal. 


\section{PENGANTAR}

\section{Latar Belakang Masalah}

Arsip merupakan dokumen primer yang memiliki ciri sebagai informasi tangan pertama dan rekaman sebuah transaksi. Arsip memiliki peranan sebagai pusat ingatan organisasi, sumber informasi, alat pengawasan, perumusan kebijakan dan pengambilan keputusan dalam sebuah organisasi. Arsip yang sudah tidak memiliki nilai guna apabila disimpan maka akan terjadinya penumpukan arsip yang sangat banyak dan akan timbulnya permasalahan bagi organisasi tersebut. Oleh karena itu, diperlukannya sebuah solusi yang dapat mengatasi permasalahan arsip tersebut, solusi dari hal tersebut adalah dengan adanya penyusutan. Penyusutan menurut Peraturan Pemerintah No 28 Tahun 2012 pasal 1 point 8 adalah :

"Penyusutan arsip adalah kegiatan pengurangan jumlah arsip dengan cara pemindahan arsip inaktif dari unit pengolah ke unit kearsipan, pemusnahan arsip yang tidak memiliki nilai guna, dan penyerahan arsip statis kepada lembaga kearsipan."

Penyusutan merupakan suatu proses pengurangan volume arsip dari arsip yang tidak memiliki nilai guna dan memiliki keterangan dimusnahkan serta menyelamatkan arsip yang berpotensi permanen dari kerusakan dan kehilangan. Sebelum melaksanakan proses penyusutan petugas dituntut untuk mengetahui umur suatu jenis arsip ketika ia aktif, inaktif dan nasib akhir yang telah ditentukan.

Penilaian dilakukan untuk menentukan nasib dan umur arsip. Michael Roper dan Laura Millar (1999:5) menyatakan bahwa
"Appraisal: The process of determining the value of records for further use, for whatever purpose, and the length of time for which that value will continue. Also known as evaluation, review or selection".

Penilaian dianggap sebagai proses memutuskan nilai dari arsip untuk digunakan lagi, untuk tujuan tertentu dan memiliki umur yang lebih panjang memiliki nilai berkelanjutan. Proses penilaian dikenal juga sebagai evaluasi, meninjau dan seleksi. Penilaian arsip bagi lembaga swasta dan BUMN terhadap dokumen perusahaan bersifat wajib sebelum dokumen tersebut diserahkan atau dimusnahkan.

Penilaian dan penyusutan arsip merupakan suatu kegiatan yang harus dilaksanakan di setiap instansi pemerintah, swasta dan organisasi BUMN. Salah satu instansi yang harus melaksanakan program tersebut adalah PT. Kereta Api Indonesia (Persero). PT. Kereta Api Indonesia (Persero) merupakan organisasi pemerintah yang bertujuan mencari keuntungan yang bergerak dalam bidang jasa transportasi di Indonesia. Perusahaan ini merupakan salah satu bagian dari Badan Usaha Milik Negara yang terfokus pada transportasi jasa angkutan kereta api di Indonesia.

\section{Rumusan Masalah}

Terjadinya ledakan arsip atau penumpukan arsip menjadi masalah yang banyak dihadapi oleh berbagai organisasi. Salah satu penyebab terjadinya penumpukan arsip adalah kegiatan penyusutan arsip tidak berjalan dengan lancar. Tulisan ini bertujuan untuk mengkaji bagaimana proses penyelenggaraan kearsipan, khususnya penyusutan arsip yang dilakukan oleh PT. Kereta Api Indonesia (Persero) sebagai salah satu BUMN di Indonesia. 


\section{Metode Penelitian}

Penelitian ini menggunakan pendekatan kualitatif dengan metode observasi partisipan. Batasan dalam pembahasan tulisan dengan judul Penilaian dan Penyusutan Dokumen Perusahaan PT. Kereta Api Indonesia (persero) adalah kegiatan penilaian arsip berdasarkan JRA atau berdasarkan nilai guna, pemindahan arsip dari unit pencipta ke unit kearsipan, penyerahan dari lembaga pencipta ke lembaga kearsipan dan kegiatan pemusnahan. Masa penelitian ini tahun 2011 sampai dengan Maret 2016.

\section{Kerangka Pemikiran}

\section{Penilaian Arsip}

Penilaian dalam manajemen kearsipan merupakan salah satu unsur yang harus diterapkan, mengingat penyusutan tidak dapat dipisahkan dengan penilaian arsip. Menurut Laksmi dkk "Penilaian arsip adalah pemeriksaan data yang dikumpulkan melalui inventaris arsip untuk menentukan nilai setiap seri arsip". Penilaian ini dilakukan dengan tujuan untuk memberikan informasi terkait masa penggunaan arsip pada saat ini ataupun pada masa yang akan datang dengan cara menganalisis isi informasi pada arsip. Selain itu, “...penilaian arsip bertujuan memberikan kepastian berapa lama arsip untuk disimpan" (Laksmi dkk, 2015).

Betty Rick menjelaskan bahwa "A records appraisal is an examination of the data gathered through the records series to the records inventory to determaine the value of each records series to the organization".
Penilaian arsip adalah pengujian sekelompok arsip melalui daftar arsip dalam menentukan nilai guna setiap seris bagi organisasi.

Nilai guna yang dimaksudkan dalam definisi di atas merupakan nilai guna yang terkandung dalam suatu arsip. Nilai guna tersebut terdiri dari nilai guna primer dan nilai guna sekunder. Penilaian dengan menggunakan nilai guna merupakan langkah awal dalam pembuatan jadwal retensi arsip. Jadwal retensi adalah jadwal pemindahan dan pemusnahan arsip sesuai dengan lama masing-masing jenis arsip disimpan pada file aktif, file inaktif, dan kemudian dimusnahkan. Penilaian dan JRA merupakan sarana penentu dalam penyusutan.

Dasar proses penilaian ini adalah jadwal retensi arsip (JRA) sebagai pedoman penentuan masa simpan dan nasib akhir dari arsip. JRA memuat unsur-unsur jenis arsip, masa simpan atau retensi arsip dan nasib akhir dari arsip. JRA ini memiliki tujuan sebagai berikut :

a. Penyisihan arsip dengan tepat bagi arsip yang tidak memiliki jangka waktu simpan lama;

b. Penyimpanan sementara arsip-arsip yang tidak perlukan lagi kepentingan administrasi; dan c. Pemeliharaan arsip-arsip yang bernilai permanen. (Wursanto, 1991:211).

JRA membantu proses pelaksanaan program penyusutan berjalan dengan tertib, mengingat fungsi dari JRA itu sendiri sebagai pedoman penyusutan arsip. 
Penyusutan arsip terdiri dari tiga kegiatan yaitu pemindahan arsip inaktif dari unit pencipta ke unit kearsipan, penyerahan arsip statis dari unit pencipta ke lembaga kearsipan dan pemusnahan arsip yang tidak bernilai guna dan berketerangan musnah dalam JRA. Proses pemindahan dokumen perusahaan dilakukan secara sistematis dan terencana. Proses ini tidak ada perbedaan antara pemindahan arsip bagi lembaga negara dan lembaga swasta yang signifikan, perbedaan tersebut hanya terletak pada pengambil keputusan atas pelaksanaan program.

Penyerahan arsip merupakan sebuah kegiatan yang akan melibatkan pihak diluar organisasi, pihak tersebut adalah lembaga kearsipan. Dokumen perusahaan yang wajib diserahkan ke lembaga kearsipan adalah yang memiliki nilai kesejarahan yang berkaitan dengan memory collective negara dan kegiatan organisasi yang bekaitan denga kegiatan negara. Tidak berbeda dengan organisasi pemerintah, tata cara penyerahan dokumen perusahaan juga harus dilaksanakan dengan pembuatan berita acara yang menerangkan waktu penyerahan, keterangan mengenai pelaksanaannya, dan disertai dengan daftar dokumen yang akan diserahkan ke lembaga kearsipan.

Selain pemindahan dan penyerahan, bentuk kegiatan lain dari penyusutan adalah pemusnahan. Pemusahan arsip dilakukan terhadap arsip yang tidak memiliki nilai guna atau berketerangan musnah berdasarkan JRA. Menurut Agus Sugiarto dan Teguh Wahyono "pemusnahan arsip dilakukan secara total sehingga tidak dapat dikenal lagi baik isi maupun bentuknya...." (Sugiarto dan Teguh Wahyono, 2015:96).

Penyusutan arsip merupakan pengurangan volume arsip dengan cara pemindahaan arsip inaktif dari unit pencipta ke unit kearsipan, penyerahan arsip dari lembaga kearsipan dan pemusnahan arsip yang tidak memiliki nilai guna. Pelaksanaan kegiatan penyusutan ini memiliki tujuan:

a. Mendapatkan penghematan dan efisiensi;

b. Pendayagunaan arsip dinamis (aktif dan inaktif);

c. Memudahkan pengawasan dan pemeliharaan terhadap arsip yang masih diperlukan dan bernilai tinggi; dan

d. Penyelamatan bahan bukti kegiatan organisasi.

Kegiatan pertama dalam penyusutan arsip yaitu pemindahan. Pemindahan arsip atau dokumen dilaksanakan terhadap arsip yang sudah memasuki fase inaktif. "Pemindahan dokumen sifatnya internal, yaitu dari unit pengolah ke unit kearsipan di lingkungan perusahaan". Pada proses pemindahan arsip yang dipindahkan harus disertai dengan berita acara dan daftar arsip pindah. Berita acara pemindahan arsip inaktif ditandatangani oleh kedua belah pihak yang menyerahkan dan menerima arsip.

Penyerahan arsip ialah menyerahkan arsip bernilai sekunder/bernilai guna sebagai bahan pertanggungjawaban nasional, tetapi sudah tidak digunakan untuk penyelenggaraan administrasi sehari-hari penciptanya. Arsip akan diserahkan ke lembaga kearsipan sesuai dengan ruang lingkup dari lembaga kearsipan tersebut. 
Berita acara dan daftar arsip serah dalam kegiatan ini merupakan berkas yang harus termuat di dalamnya, penandatangan berita acara dilakukan oleh pejabat kedua belah pihak yaitu organisasi yang menyerahkan arsip dan lembaga kearsipan yang menerima arsip.

Kegiatan ketiga dalam penyusutan arsip adalah pemusnahan. Pemusnahan atau disposal arsip adalah tindakan atau kegiatan menghancurkan secara fisik arsip yang sudah berakhir fungsinya serta yang tidak memiliki nilai guna. Kegiatan pemunsahan arsip dilakukan secara total hingga fisik dan isi informasi arsip sudah tidak dikenali lagi. Tanggung jawab kegiatan pemusnahan arsip terletak pada penanggung jawab kegiatan kearsipan di suatu organisasi. Proses pemusnahan disaksikan oleh dua orang pejabat dari bidang hukum dari organisasi tersebut. Metode pemusnahan arsip meliputi metode pencacahan, pembakaran, pemusnahan kimiawi, dan pembuburan. Sama halnya dengan pemindahan dan penyerahan, kegiatan pemusnahan arsip disertai dengan berita acara dan daftar arsip yang dimusnahkan. Berita acara dan daftar arsip musnah ditandatangani oleh penanggung jawab pemusnahan bersama dua orang saksi.

\section{Dokumen}

Dokumen adalah unit informasi yang terekam, terstuktur, diterbitkan atau tidak diterbitkan, dalam bentuk cetak (hard copy) atau bentuk elektronik dan dikelola sebagai unit diskrit dalam sistem informasi. Dokumen dan arsip merupakan hal yang sama, yang membedakan hanyalah penggunaan istilah. Arsip bagi perusahaan memiliki peran dalam pengembangan proses bisnis yang digelutinya, dari arsip sebuah perusahaan dapat meningkatkan pendapatannya dengan cara membuka arsip terdahulunya dan mengevaluasi kesalahan atau kelemahan yang terjadi sehingga mampu meminimalisir kesalahan atau kelemahan. Selain itu, arsip memiliki peran penting dalam proses penyajian informasi bagi pimpinan untuk membuat keputusan dan merumuskan kebijakan.

\section{Perusahaan}

Perusahaan adalah organisasi yang bergelut dalam aktivitas bisnis yang berhubungan dengan perniagaan barang dan jasa. Jenis perusahaan sangat beragam mulai dari perusahaan perorangan, perusahaan komoditer (CV) dan perseroan terbatas (PT). Bentuk perusahaan yang paling banyak digunakan di Indonesia adalah bentuk perusahaan dengan jenis Perseroan Terbatas atau PT. Landasan hukum mengenai PT sudah diatur dalam Undangundang Nomor 40 Tahun 2007 tentang Perseroan Terbatas. Salah satu jenis dari bentuk perusahaan perseroan terbatas adalah PT Persero BUMN.

PT-Persero BUMN, yaitu perseroan terbatas yang telah go public (PT-Go Public), yakni perseroan sebagai modalnya telah dimiliki public dengan jalan membeli saham melalui pasar modal (capital market) melalui bursa saham. 
Pembagian modal pada perusahaan berbentuk PT-Persero BUMN ini telah diatur dalam Undang-undang Nomor 19 Tahun 2003 tentang Badan Usaha Milik Negara. Secara eksplisit menyatakan bahwa perusahaan perseroan, yang selanjutnya disebut persero adalah BUMN yang berbentuk perseroan terbatas yang modalnya terbagi dalam saham yang seluruh atau paling sedikit $51 \%$ (lima puluh satu persen) sahamnya dimiliki oleh Negara Republik Indonesia yang tujuan utamanya mengejar keuntungan.

\section{PEMBAHASAN}

\section{Penilaian dan Penyusutan Dokumen}

Perusahaan PT. Kereta Api Indonesia (KAI) (Persero)

Kegiatan penyusutan dokumen perusahaan di PT. KAI (Persero) dilakukan dalam dua garis besar proses yaitu penilaian dokumen dan penyusutan dokumen. Semua tindakan penyusutan dokumen perusahaan diawali dengan kegiatan penilaian dokumen perusahaan. Hasil penilaian tersebut yang menjadi acuan dalam menentukan dokumandokumen yang akan disusutkan baik itu dengan tindakan pemusnahan, pemindahan, maupun penyerahan.

\section{Penilaian}

Penilaian akan sangat menentukan tehadap penyusutan, mengingat fungsi dari penilaian akan menghasilkan sebuah daftar arsip yang akan diserahkan, dimusnahkan atau dipindahkan dalam rangka penyelenggaraan penyusutan di suatu instansi. Definisi penilaian dapat dipahami sebagai berikut
"Proses mengevaluasi aktivitas perusahaan atau instansi untuk menentukan rekod mana yang perlu dipertahankan dan berapa lama rekod itu disimpan guna memenuhi kebutuhan aktifitas instansi atau perusahaan, persyaratan pertanggungjawaban organisasi dan harapan masyarakat." (Basuki, 2003:19).

Proses penilaian dapat dilakukan dengan dua cara yaitu penilaian berdasarkan nilai guna dan penilaian berdasarkan jadwal retensi. Penilaian arsip di PT. KAI (Persero) didasarkan kepada jadwal retensi arsip atau JRA dan nilai guna.

JRA terbagi dalam dua bagian yaitu JRA subtantif dan JRA fasilitatif. JRA subtantif merupakan JRA dengan jenis arsip terkait masalah pokok yang menjadi tugas dan fungsi dari organisasi tersebut, sedangkan JRA fasilitatif merupakan JRA dengan jenis arsip tentang unsur penunjang organisasi.

JRA subtantif PT. Kereta Api Indonesia (Persero) terdiri dari :

1) Komersialisasi Kereta Api;

2) Operasional Kereta Api;

3) Prasarana Kereta Api;

4) Sarana Kereta Api; dan

5) Keselamatan, Keamanan dan Hygiene Kereta Api.

JRA subtantif di PT. KAI (Persero) memiliki acuan pada perkembangan bisnis di perusahaan.

JRA fasilitatif PT. KAI (Persero) terdiri dari :

1) Kepegawaian;

2) Kepemilikan Aset;

3) Diklat;

4) Hukum;

5) Kerjasama; 
6) Organisasi dan Tata Laksana;

7) Pengendalian Dokumen;

8) Perpustakaan (Bibliotik / Bahan Pustaka);

9) Perlengkapan dan Pelelangan;

10)Perencanaan Perusahaan;

11)Pengawasan/Pemeriksaan;

12) General Affair dan Humas;

13)Keuangan; dan

14)Sistem Informasi.

JRA fasilitatif PT. KAI (Persero) mengacu pada beberapa sumber diantaranya adalah:

1. Peraturan Kepala ANRI No. 8 Tahun 2015 tentang Jadwal Retensi Arsip Kepegawaian dan Pejabat Negara;

2. Peraturan Kepala ANRI No. 6 Tahun 2013 tentang Keuangan;

3. Peraturan Kepala ANRI No. 12 Tahun 2009 tentang JRA keuangan dan Non keuangan;

4. Peraturan Kepala ANRI No. 19 Tahun 2009 tentang Pedoman Retensi Arsip Urusan Kearsipan;
5. Peraturan Kepala ANRI No. 22 Tahun 2015 tentang Tata Cara Penetapan Jadwal Retensi Arsip.

\section{Proses Pembuatan dan Penyempurnaan JRA}

Proses pembuatan JRA sudah dimulai ketika unit ESD tercipta yaitu pada tahun 2009. Penyempurnaan JRA dilakukan dengan tujuan memperbaharui beberapa point dalam JRA dan mengakomodir semua jenis arsip yang dimiliki oleh PT. KAI (Persero). Selain itu tujuan dari penyempurnaan JRA adalah untuk memenuhi persyaratan legalisasi terkait persetujuan JRA oleh Kepala ANRI.

Proses pembaharuan ini dimulai sejak tahun 2015 dengan diawalinya pembentukan tim penilai, pengiriman surat terkait pengajuan JRA, pengiriman JRA, ANRI melaksanakan telaah pada JRA tersebut dan kemudian dilakukan pembahasan terkit JRA tersebut yang kemudian tahap akhirnya adalah pengesahan JRA oleh Kepala ANRI. Tim penilai ini terbentuk sejak tahun 2015 sampai 30 hari kalender setelah JRA final. Tim penilai terdiri dari:

1. Ketua tim : Dwi Purnamasari Vice President Corporate Document Management

2. Sekretaris : Dasril Manager Documents Legal \& File

3. Anggota : Happy Susanti Assistant Manager Record Center Muh Kodar Assistant Manager General Archives Erna $\mathrm{P}$ Assistant Manager Land Ownership Document 
Penentuan masa retensi ditelaah melalui metode diskusi antara tim penilai dengan perwakilan dari ANRI. Setelah selesai pembahasan JRA dilaksanakannya penerbitan berita acara pembahasan JRA yang ditandatangani oleh kedua belah pihak. Langkah selanjutnya adalah JRA yang telah selesai dibahas di setujui oleh kepala ANRI dan di legalkan oleh Direktur Utama PT. KAI (Persero).

\section{Penyusutan}

Berdasarkan Peraturan Kepala ANRI Nomor 25 Tahun 2012 tentang Pedoman Pemusnahan Arsip, Pasal 1 Point 34, disebutkan penyusutan arsip adalah kegiatan pengurangan jumlah arsip dengan cara pemindahan arsip inaktif dari unit pengolah ke unit kearsipan, pemusnahan arsip yang tidak memiliki nilai guna, dan penyerahan arsips statis kepada lembaga kearsipan. Kegiatan penyusutan meliputi :

\section{a. Pemindahan}

Proses pemindahan arsip di PT. KAI (Persero) dilakukan secara sistematis dan berkala. Pemindahan arsip ini tidak hanya dilakukan terhadap arsip inaktif saja akan tetapi dilakukan terhadap arsip aktif, hal ini didasarkan atas aspek keamanan dokumen dan ketersediaan tempat penyimpanan arsip. Pemindahan arsip aktif diserahkan kepada unit dokumen legal, dokumen umum dan dokumen asset tergantung pada jenis arsip yang akan diserahkan.

Pemindahan arsip ini dilaksanakan oleh unit pencipta dan record center. Unit pencipta terdiri dari semua unit yang ada di PT. KAI (Persero), Sedangkan unit kearsipan berada dibawah Unit Dokumen Legal yang berada di bawah Unit Dokumen yang akan bertanggung jawab kepada Executive Secretary dan Direktur Utama. Setiap tahunnya Record Center menerima pemindahan arsip inaktif dengan jumlah lebih dari 30.000 berkas/tahun. Berikut rincian data arsip inaktif yang diterima oleh PT. Kereta Api Indonesia (Persero): 
Tabel 1

Pemindahan Arsip Inaktif PT. KAI (Persero)

Tahun 2011-2016

\begin{tabular}{|c|c|c|}
\hline Tahun & Jenis Arsip & Jumlah \\
\hline \multirow{4}{*}{2011} & Asset & 17.75 \\
\hline & Legal & 683 \\
\hline & Umum & 66.594 \\
\hline & Jumlah & 85.024 Berkas \\
\hline \multirow{4}{*}{2012} & Asset & 10.272 \\
\hline & Legal & 833 \\
\hline & Umum & 1.017 .125 \\
\hline & Jumlah & 1.028.230 Berkas \\
\hline \multirow{4}{*}{2013} & Asset & 12.673 \\
\hline & Legal & 1.312 \\
\hline & Umum & 64.749 \\
\hline & Jumlah & 78.734 Berkas \\
\hline \multirow{4}{*}{2014} & Asset & - \\
\hline & Legal & 7.195 \\
\hline & Umum & 29.526 \\
\hline & Jumlah & 36.721 Berkas \\
\hline \multirow{4}{*}{2015} & Asset & 955 \\
\hline & Legal & 384 \\
\hline & Umum & 83.155 \\
\hline & Jumlah & 84.494 Berkas + 20 Dus \\
\hline \multirow{4}{*}{$\begin{array}{l}2016 \text { (Januari s/d } \\
\text { Maret ) }\end{array}$} & Asset & - \\
\hline & Legal & - \\
\hline & Umum & 8.101 \\
\hline & Jumlah & 8.101 Berkas + 73 Dus \\
\hline \multicolumn{2}{|c|}{$\begin{array}{l}\text { Jumlah Arsip Inaktif yang telah diterima oleh } \\
\text { record centre per } 17 \text { Maret } 2016\end{array}$} & 1.321.304 Berkas + 93 Dus \\
\hline
\end{tabular}

Sumber: Data Primer 
Pemindahan yang dilakukan secara langsung ke record center memiliki alur sebagai berikut:

1) Unit yang akan menyerahkan arsip mengirimkan nota dan daftar arsip yang ditujukan kepada Vice President Document Management. Penyampaian nota bisa disampaikan melalui Rail Document System (RDS) atau secara langsung disampaikan ke VP Document Management

2) Vice President Document Management menerima nota yang kemudian dilakukan disposisi kepada manajer dokumen legal.

3) Pengiriman Dokumen ke record center

4) Dokumen diterima oleh asisten manajer Record Centre atau staf pelaksana

5) Dokumen ditempatkan di ruang transit yang kemudian akan dilakukan verifikasi

6) Verifikasi dilakukan terhadap daftar arsip dan fisik arsip, dilakukan pencocokan antara keduanya. Apabila ada arsip yang belum terdaftar dalam daftar arsip maka petugas verifikasi harus menambahkan data tersebut kedalam daftar dan menghapus daftar arsip yang tidak ada fisiknya.

7) Pembuatan Berita Acara yang ditandatangani oleh kedua belah pihak

8) Penataan dan penyimpanan arsip pada rak di depo arsip
Pemindahan arsip inaktif di PT. KAI (Persero) masih dilaksanakan sepenuhnya ke records center, belum ada pemindahan yang dilaksanakan ke unit kearsipan di tingkat lembaga kearsipan. Mengingat pembaharuan dan pengesahan JRA yang dimiliki perusahaan masih dalam proses.

Arsip inaktif yang telah diserahkan oleh unit pencipta ke records center merupakan tanggung jawab dari Record Center. Pengelolaan, perawatan dan pengawasan terhadap arsip merupakan aspek penting yang harus dilakukan. Untuk menjaga arsip dalam keadaan baik proses perawatan yang dilakukan oleh Record Center PT. KAI (Persero) adalah pemberian kamper dan silicagel, pembersihan debu, cuci besar dan fumigasi. Pengolahan arsip inaktif merupakan hal yang sangat penting dilakukan, arsip yang tertata dengan baik akan sangat membantu dalam efektifitas dan efisiensi kerja. Tahapan pengolahan arsip inaktif di record center sebagai berikut:

1) Pemeriksaan Fisik Arsip

Pemeriksaan antara daftar arsip dan fisik arsip yang diserahkan, hal ini dilakukan guna pembuatan daftar arsip pada lampiran berita acara.

2) Olah Data

Data dari hasil pemeriksaan fisik dan informasi arsip di input kedalam sebuah program, dengan tujuan tersentralnya data dan menghasilkan output berupa daftar arsip. 
3) Scan

Proses scan merupakan proses alih media arsip dari media konvensional ke media elektronik atau digital. Proses ini dilakukan dengan tujuan untuk mempermudah pencarian dan bagian dari proses preservasi arsip.

4) Penataan Arsip kedalam Boks dan Pemberian Kamper + Silica Gel.

5) Pembuatan Indeks.

6) Document Opname.

Document opname merupakan kegiatan penyesuaian kembali antara data dengan fisik arsip, proses ini merupakan bagian dari kontrol terhadap koleksi arsip yang dimiliki oleh PT. KAI (Persero).

Record centre merupakan sebuah gedung yang difungsikan untuk menyimpan, mengolah dan merawat arsip inaktif yang dimiliki oleh PT. KAI (Persero). Record centre terletak di Jalan Sukabumi No. 20 A di komplek Gudang Persediaan Cikudapateuh dan merupakan bangunan cagar budaya yang dilindungi oleh UU No. 5 Cagar Budaya tahun 1992. Fasilitas penunjang yang dimiliki record centre yaitu komputer, printer, scanner, craine, laci cabinet, rak arsip, boks arsip, springkel, plastik, tabung pemadam, lemari, masker, sarung tangan, jas kerja, gordeng dan blower.

\section{a. Pemusnahan}

Pemusnahan dilakukan terhadap arsip yang telah habis masa retensinya dan berketerangan dimusnahkan atau arsip yang tidak memiliki nilai guna bagi kepentingan perusahaan ataupun negara. "Metode pemusnahan arsip dinamis inaktif meliputi metode pencacahan, pembakaran, pemusnahan kimiawi dan pembuburan" (Basuki, 2003:320). Manfaat dari dilakukannya pemusnahan arsip yaitu mampu meningkatkan efektifitas dan efisensi pekerjaan, tersedianya rak arsip untuk arsip inaktif dan mampu mempermudah penemuan kembali arsip inaktif.

Proses pemusnahan harus dilakukan secara sistematis dan terstruktur guna menghindari kesalahan dalam proses pemusnahan. Sebelum melaksanakan pemusnahan sebaiknya sebuah organisasi memiliki standard operasional prosedur pemusnahan agar mampu memberikan arahan langkah apa saja yang harus ditempuh dan batasan apa yang tidak boleh dilaksanakan.

PT. KAI (Persero) belum melakukan pemusnahan dikarenakan masih dalam tahap pembahasan SOP Pemusnahan arsip dan belum selesainya legalisasi JRA. SOP Pemusnahan arsip ini nantinya akan digunakan oleh seluruh PT. KAI (Persero) baik di pusat maupun di daerah. 
Selain itu, pembuatan SOP yang dilakukan oleh perusahaan telah memenuhi ketentuan yang tertuang dalam Peraturan Pemerintah Nomor 87 Tahun 1999 tentang Tata Cara Penyerahan dan Pemusnahan Dokumen Perusahaan pasal 11 yang menyatakan bahwa setiap pemusnahan dokumen perusahaan wajib didasarkan atas keputusan pimpinan perusahaan atau keputusan pejabat yang ditunjuk dilingkungan perusahaan yang bersangkutan.

Dalam perencanaannya alur pemusnahan yang dilakukan oleh PT. KAI (Persero) terbagi menjadi dua yaitu tahap persiapan dan tahap pelaksanaan. Tahap persiapan terdiri dari:

1) Unit Pencipta melakukan penyeleksian arsip yang akan di usulkan musnah

2) Penyerahan arsip ke unit kearsipan disertai daftar arsip usul musnah

3) unit kearsipan melaksanakan penyeleksian dan penilaian arsip

4) Mengajukan surat permohonan persetujuan pemusnahan arsip kepada Kepala ANRI untuk arsip dengan retensi sekurang kurangnya 10 tahun atau tanpa JRA sedangkan untuk arsip dengan retensi dibawah 10 tahun melalui persetujuan Direktur Utama dengan tembusan kepada ANRI.

5) Unit kearsipan mengirimkan nota dinas berupa pemberitahuan dan pendamping arsip fisik yang dikirim kepada Unit Material Stock sebagai pelaksana pemusnahan arsip . Unit material stok merupakan unit dibawah Managing Director of Logistic and Railways
Assets dengan EVP Logistic, yang memiliki tanggung jawab dan tugas pokok dalam mengelola pergudangan yang meliputi penyimpanan, pendistribusian, pengalihan dan penghapusan barang persediaan, mengelola sistem informasi persediaan, pelaksanaan stock opname dan penyusunan laporan posisi persediaan dan buku pedoman harga satuan harga serta menyususn katalogisasi barang persediaan, buku spesifikasi teknis barang persediaan dan menyusun regulasi logistik.

Tahap pelaksanaan pemusnahan terdiri darikegiatan :

1) Pelaksanaan pemusnahan dilaksanakan dalam waktu paling lambat 45 hari setelah dikirimkannya nota dinas oleh unit material stock;

2) Setelah dilaksanakan pemusnahan arsip, diterbitkan berita acara pemusnahan arsip; dan

3) Unit kearsipan melaporkan seluruh kegiatan kepada Direktur Utama PT. KAI (Persero).

Perencanaan program pemusnahan yang dilakukan oleh PT. KAI (Persero) sudah sesuai dengan peraturan yang berlaku. Peraturan tersebut yaitu Peraturan Pemerintah Nomor 28 Tahun 2012 tentang Pelaksanaan UndangUndang Nomor 43 Tahun 2009 Tentang Kearsipan pada pasal 66 dan Peraturan Pemerintah Nomor 87 Tahun 1999 tentang Tata Cara Penyerahan dan Pemusnahan Dokumen Perusahaan. 


\section{a. Penyerahan}

Aspek lain dari penyusutan selain pemindahan dan pemusnahan adalah penyerahan. "Penyerahan ialah menyerahkan arsip bernilai sekunder/bernilai guna sebagai bahan pertanggungjawaban nasional, tetapi tidak diperlukan untuk penyelenggaraan administrasi sehari-hari kepada Arsip Nasional Republik Indonesia" (Laksmi, 2015:224). Penyerahan arsip diserahkan dari organisasi pencipta ke lembaga kearsipan, mengingat PT. KAI (Persero) berada pada level nasional sehingga penyerahan arsip ke lembaga kearsipan di tingkat nasional yaitu ANRI. Penyerahan arsip statis oleh PT. KAI (Persero) baru pertama kali dilaksanakan, pelaksanan penyerahan berlangsung pada hari Selasa tanggal 1 Desember 2015 yang bertempat di Kantor ANRI Jl. Ampera Raya No. 7 Jakarta Selatan.

Proses persiapan penyerahan arsip memakan waktu satu bulan termasuk koordinasi dengan pihak ANRI dan pelaksanaan. Prosedur penyerahan arsip mengacu pada Keputusan Direksi Perusahaan Umum Kereta Api Nomor KEP.U/UM.002/III/1/KA-1996 Tentang Sistem Administrasi Perkantoran Perusahaan Umum KeretaApi.

Proses persiapan arsip yang akan diserahkan :

1) Rapat internal ESD dan kesepakatan merencanakan penyerahan;
2) Berkoordinasi dengan Unit Humas, mengingat unit humas yang berkompeten di bidang pendokumentasian kegiatan;

3) Pengumpulan arsip dari unit dokumen;

4) Pengiriman Nota Pemberitahuan akan dilaksanakannya penyerahan arsip ke EVP Corporate Secretary dan Direktur Umum;

5) Penyampaian surat keluar kepada ANRI terkait akan dilaksanakannya penyerahan arsip statis;

6) Konfirmasi pelaksanaan penyerahan arsip;

7) Pengkajian ulang atau evaluasi terhadap arsip yang akan diserahkan dengan kordinasi dengan ANRI tentang kelayakan penyerahan arsip;

8) Penetapan arsip yang akan diserahkan;

9) Pelaksanaan penyerahan arsip; dan

10)Penandatanganan Berita Acara.

Arsip yang diserahkan oleh PT. KAI (Persero) adalah arsip yang sudah memasuki fase statis dan telah melalui proses telaah yang dilakukan oleh perusahaan dan pihak ANRI. Dari penjelasan diatas penyerahan arsip yang dilaksanakan oleh PT. KAI (Persero) telah sesuai dengan PP Nomor 28 Tahun 2012 tentang Pelaksanaan Undang Undang Nomor 43 Tahun 2009 tentang Kearsipan pada pasal 81 dan PP Nomor 87 Tahun 1999 tentang Tata Cara Penyerahan dan Pemusnahan Dokumen Perusahaan Bab II Tata Cara Penyerahan Pasal 7 dan Pasal 8. 


\section{KESIMPULAN}

PT. KAI (Persero) dalam satu tahun mampu menciptakan arsip lebih dari ratusan berkas, sehingga kapasitas sarana simpan/daya tampung arsip semakin berkurang tiap harinya. Arsip yang sudah memasuki fase inaktif mulai dipindahkan ke records center, pemindahan tersebut disertai daftar arsip dan diterbitkan berita acara jika proses verifikasi antara daftar arsip dan fisik arsip telah selesai. Arsip yang memiliki nilai yang bersejarah dan menyangkut memori kolektif negara diserahkan ke lembaga kearsipan yaitu ANRI dengan disertai berita acara. Arsip yang tidak memiliki nilai guna dan berketerangan musnah dibuatkan daftar arsip usul musnah, dan harus menunggu hingga pembuatan SOP Pemusnahan PT. KAI (Persero) diselesaikan. Pelaksanaan tiga kegiatan penyusutan tersebut sebelumnya harus diawali dengan kegiatan penilaian.

Proses penilaian yang dilaksanakan oleh PT. KAI (Persero) dilaksanakan dengan menggunakan penilaian yang berdasarkan JRA. Penyempurnaan dan pembaharuan JRA dilaksanakan pada sejak tahun 2015. JRA yang disusun oleh PT. KAI (Persero) harus diajukan dan disetujui oleh ANRI. Pedoman yang digunakan dalam program penilaian dan penyusutan dokumen perusahaan yaitu: UU No. 43 Tahun 2009, UU No. 8 Tahun 1997, PP No. 12 Tahun 2012, PP No. 87 Tahun 1997, Peraturan Kepala ANRI No. 25 tahun 2012, dan Keputusan Direksi Perusahaan Umum Kereta Api No. KEP.U/UM.002/III/KA-1996. 


\section{DAFTAR PUSTAKA}

Basuki, Sulistyo. 2003. Manajemen Arsip Dinamis. PT. Gramedia Pustaka Utama, Jakarta.

Laksmi. 2015. Manajemen Perkantoran Modern. PT. Raja Grafindo Persada, Jakarta.

Michael Roper and Laura Millar (eds). 1999. Building Records Appraisal System. Internasional Records Management Trush, London.

Sugiarto, Agus dan Teguh Wahyono. 2015. Manajemen Kearsipan Modern. Gava Media, Yogyakarta.
Wursanto, Ig. 1991. Kearsipan 2. Kanisius, Yogyakarta.

\section{Peraturan}

Undang-undang No. 23 Tahun 2009 tentang Kearsipan

Peraturan Pemerintah Nomor 28 tahun 2012 tentang Pelaksanaan Undang-undang Nomor 43 Tahun 2009

Peraturan Kepala Arsip Nasioanal Republik Indonesia Nomor 25 Tahun 2012 tentang Pedoman Pemusnahan Arsip 